\title{
DIE GESKIEDENIS VAN AFDELING LOGISTIEK
}

Maj A.C. Bergh*

In the eight years of its existence, the Section Logistics has become a strong Staff Section numbering 215 members, including Permanent Force Members, National Servicemen and Civilian members. Excellent co-operation is maintained throughout between the Section, the arms of the Defence Force, other Staff Sections and Armscor in order to promote an efficient logistics machine and for the benefit of the SADF as a whole. The article herunder deals with the origin and development of the Section Logistics.

\section{Historiese oorsig}

Ingevolge ' $n$ opdrag van die destydse Kommandant-generaal van die Suid-Afrikaanse Weermag, is 'n projekspan in Junie 1972 aangestel om 'n studie te onderneem tov die bevel- en beheerstruktuur van die SAW en om besondere aandag te gee aan 'n eenvoudige maar doeltreffende topstruktuur wat aan die vereistes van die SAW sou beantwoord. Die projekspan het ' $n$ detailondersoek na die funksies van bevelvoering en departementele bestuur geloods. Die vyfde verslag oor die Logistiese Funksie, het op 22 Junie 1973 die lig gesien. Die belangrikste aanbevelings in dié verslag kan soos volg opgesom word:

Daar is aanbeveel dat Hoof van Weermagadministrasie/Kwartiermeester-generaal beskou word as die kernorganisasie waarom die volwaardige en gesuiwerde logistiese stafafdeling op die volgende wyse gevorm sal word:

Weglating van die nie-logistiese afdelings, te wete afdeling Direkteur-generaal Personeel, Direkteur-generaal Algemene Administrasie en Direkteur-generaal Bestuurstelsels;

Inverplasing van die logistiese afdelings, Direktorate Projekte en Logistiese Beplanning vanaf Hoof van Verdedigingstaf (HVS) en die seksie Voorraadadministrasie vanaf die destydse Komptroleur, SAW

Daar is verder aanbeveel dat 'n detailondersoek na die suiwering van die logistiese funksie, die afbakening van verantwoordelikhede daarvoor en die sentralisasie van die bestuur daarvan aan 'n verteenwoordigende komitee van gebruikers en logistici oorgelaat word.

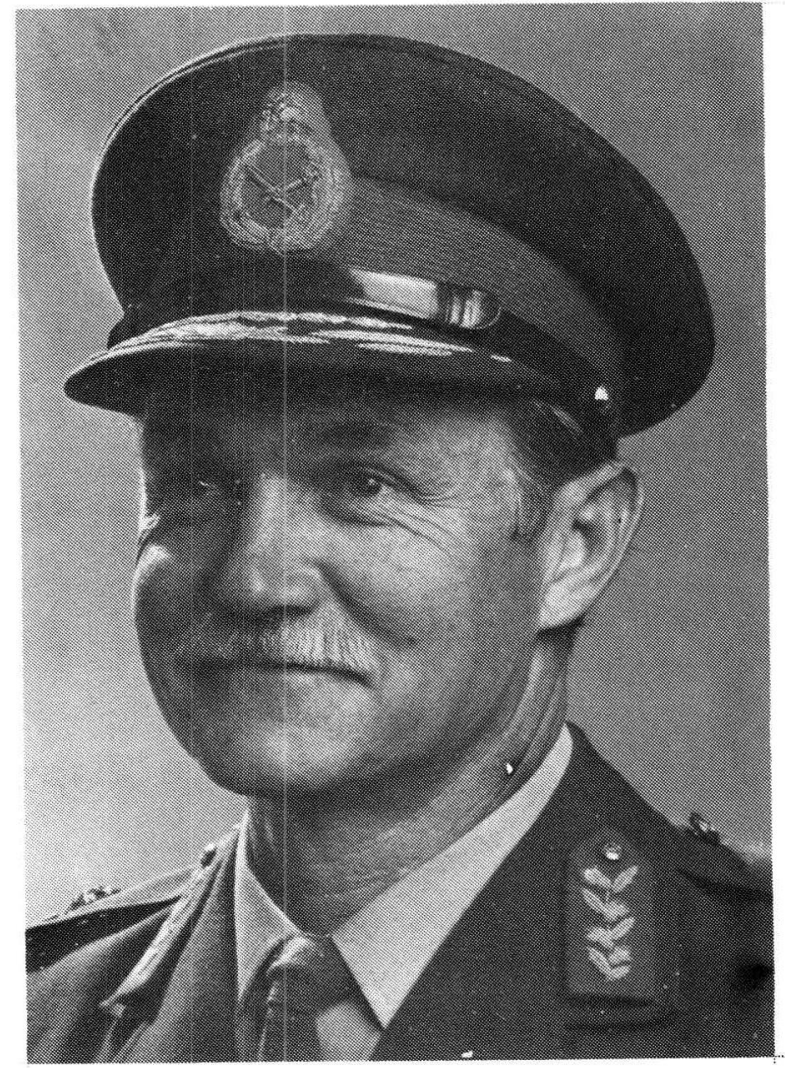

Lt-genI I. Lemmer, SD, SM Hoof van Staf Logistiek sedert 1 Augustus 1978

'n Volwaardige en gesuiwerde logistiese stafafdeling moes ook vir elkeen van die weermagsdele daargestel word.

Die projekspan het die funksies van die Logistiese Stafafdeling as die 'beplanning en koördinering van en toesig oor die verkrygings-, voorsienings-, onderhouds-, transport-, konstruksie-, ontruimings- en ander verwante logistiese missies van die Bevelvoerder' gesien. Die aanbevelings van die projekspan is deur hoër gesag goedgekeur. 


\section{Afdeling Logistiek}

Die Afdeling Logistiek is met ingang van 15 April 1974 in die lewe geroep. As kern van die nuwe Afdeling is bepaal dat die volgende elemente na die beheer van Hoof van Staf Logistiek (HSL) oorgeplaas word:

Kwartiermeester-generaal in sy geheel.

Direktoraat Logistiese Beplanning vanaf Hoof van Verdedigingstaf.

Die Seksie Voorraadbeheer vanaf die toenmalige Komptroleur, SAW.

Die beheer van Afdeling Logistiek is aan die voormalige Hoof van Weermagsadministrasie, It genl H.P. Laubscher toegewys. Dit dien verder gemeld te word dat slegs die Direktoraat Logistiese Beplanning na Afdeling Logistiek oorgeplaas is

\section{Ontwikkeling}

'n Verdere verwikkeling in die organisasie van die logistiese funksie het in 1974 plaasgevind toe die aanbevelings deur die projekspan geïmplementeer is. ' $n$ Ondersoekspan onder leiding van genl-maj L.H. Groenewald het aanbeveel dat HSL en sy stafafdeling deel van die Verdedigingstaf van H SAW moes uitmaak, met die algemene doelstelling 'om die oorhoofse bestuur van die logistiese funksie in die SAW te behartig' en dat KMG en sy organisasie op die uitvoerende vlak as apartstaande dienslewerende instelling onder H SAW geplaas word met die algemene doelstelling 'om bepaalde logistiese dienste aan die SAW te lewer'. Hierdie aanbevelings is met ingang van 1 November 1974 deur die Minister van Verdediging goedgekeur. Op 31 Desember 1974 het It-genl H.P. Laubscher met pensioen uit diens van die SAW getree en is met ingang van 1 Januarie 1975 deur It-genl H.A. Kotzé opgevolg.

Op 1 April 1975 sluit genl-maj W.A. Lombard hom by die geledere van HSL aan en wel in die hoedanigheid as Direkteur-generaal Logistiese Operasionele Beplanning. Gedurende 1975 beskik die Afdeling oor die poste van ' $n$ It-genl, genl-maj, brig en 'n paar ander offisiere wat gevul is deur lede wat vanaf hulle vroeëre hoofkwartiere na HSL oorgekom het. Weinig vordering kon gemaak word met die skepping van 'n organisasie wat op gesonde beginsels fundeer is. Verskeie voorstelle is geformuleer, dog dit is waar dit gebly het.

\section{Ontbinding van Direkteur-generaal Algemene Administrasie}

Met die ontbinding op 1 November 1975 van die Direkteur-generaal Algemene Administrasie, word die Seksie Spesiale Take met poste en personeel na Afdeling Logistiek oorgeplaas en die Direktoraat Katalogisering en Kodifikasie (DKK) met poste en personeel met die ontbinding van Direkteur-generaal Bestuurstelsels. Op dieselfde datum word poste en personeel van Projek KONVOOR, stelsel Alpha en ander stelseldienste met ' $n$ logistiese inslag formeel na Afdeling Logistiek oorgeplaas, nadat daar vroeër reeds informeel op hierdie stap ooreengekom was.

Aan die begin van 1976 verskil die organisasie van Afdeling Logistiek weinig van wat dit was toe dit in 1974 daargestel is; dit is op daardie stadium nog steeds nie 'n organisasie wat deur die bestuur- en diensstaatondersoek sy beslag gekry het nie. Die Afdeling bestaan uit ' $n$ aantal saamgeflanste elemente waaronder nou ook DKK en Projek KONVOOR tel. Intussen het HSL die Afdeling georganiseer op voorstelle van Direkteur-generaal Organisasiestudies (DGOS Sadm Edwards), maar hierdie reorganisasie was nooit vir goedkeuring voorgelê nie. Op hierdie stadium is daar voorsiening gemaak vir twee direkteurs-generaal en 'n aantal direktorate, terwyl die interne dienste van die Afdeling op daardie stadium nog deur Afdeling Operasies behartig is. Op 23 Januarie 1976 word deur DGOS aanbeveel dat 'n Direktoraat Logistiese Stelsels as deel van Afdeling Logistiek daargestel word om die funksies van logistiese stelselbeplanning en stelselbestuur saam te vat. Genl-maj W.A. Lombard tree miv 30 September 1976 met pensioen uit die diens van die SAW en word deur genl-maj W.J. Coetser as Direkteur-generaal Logistiese Operasionele Beplanning met ingang 1

Oktober 1976, opgevolg. Tot aan die einde van 1976 is daar nog geen werklike vordering met die toestandkoming van ' $n$ volwaardige Afdeling Logistiek gemaak nie.

\section{Direktoraat Logistiese Stelsels}

Aan die begin van 1977 is ' $n$ aantal personeellede na die Afdeling inverplaas, alhoewel hulle nog deur poste elders in die SAW gedra was; 'n toestand wat nog tot einde van daardie jaar voortduur. Gedurende 1977 het Direkteur Organisasiestudies (DOS) aangedui dat ' $n$ ondersoek 
tydens daardie jaar sou plaasvind om die Afdeling op 'n gesonder grondslag te plaas en op 1 Maart 1977 is die organisasie van die Direktoraat Logistiese Stelsels (D Log S) amptelik daargestel.

Op 1 Julie 1977 het 'n projekspan van DOS met ' $n$ ondersoek by die Afdeling begin, vanaf welke datum die Afdeling ook verantwoordelik vir die behartiging van sy eie interne administrasie was. Tydens die eerste besoek van H SAW aan hierdie Afdeling, is die voorgestelde organisasie dan ook aangebied. Agv die probleem wat ontstaan het met die gebrek aan goedgekeurde poste vir die Afdeling en as gevolg van die verwagte vertraging met die ondersoek van die DOS-span, het die Afdeling Logistiek en Afdeling Personeel oorleg gepleeg en laasgenoemde het ingestem dat die Afdeling self ' $n$ interim organisasie ontwerp en vir goedkeuring voorlê. Die organisasie is ontwerp en op 6 September 1977 is dit aan HSP vir prosessering voorgelê. Met die ontwerp van hierdie organisasie is daar vir die eerste keer van die filosofie van ontwerp, samestelling en aanwending, wat ook die basis van die gesamentlike beplanningsproses vorm, gebruik gemaak. Hierdie drie elemente is onderskeidelik deur die aktiwiteite van die Direktorate Logistiese Beplanning, Materiële Programme en Logistiese Operasies gedek wat deur die Direkteur-generaal Logistiese Operasionele Beplanning gekoördineer is. Verder is daar voorsiening gemaak vir 'n Seksie Logistiese Administrasie wat al daardie aspekte wat nie logies by die ander direktorate ingepas het nie, asook Interne Dienste, moes behartig. DKK en D Log $S$ is as spesialis-direktorate gesien wat direk aan HSL rapporteer.

Teen die einde van 1977 het die DOS-span 'n interimverslag uitgebring en aan HSL vir kommentaar voorgelê. Op 9 Desember 1977 is die organisasie, soos deur Afdeling Logistiek self opgestel, goedgekeur. Aan die hand van die kommentaar op die DOS-verslag en deur middel van konsultasie tussen HSL en HSP is daar besluit dat die Afdeling vir een jaar volgens die selfgeskepte organisasie moes funksioneer. Hierna moes 'n opvolgondersoek deur HSP gedoen word.

\section{Direktoraat Militêre Ingenieurswese}

Aan die begin van 1978 is ' $n$ ingenieursoffisier by die Afdeling ingedeel en het die behoefte aan 'n direktoraat wat na ingenieursaspekte kon om- sien, begin uitkristalliseer, terloops 'n element wat reeds deur die Bevel- en Beheerprojekspan in 1973 aanbeveel is. Daar is gevolglik aansoek gedoen vir die skepping van 'n Direktoraat Militêre Ingenieurswese wat die Seksie Materiële Beleid moes akkommodeer. Hierdie versoek is goedgekeur en die nuwe direktoraat het direk onder HSL ressorteer. H SAW het in 1978 die Afdeling ' $n$ tweede keer besoek en aan die einde van daardie jaar het die bestaande Afdeling, soos dit toe daaruitgesien het, met die uitsondering van DKK, vanaf Verdedigingshoofkwartier na Poynton-gebou verhuis.

Genl-maj I. Lemmer wat vanaf 1 Julie 1978 tot 31 Julie 1978 Adjunk Hoof van Staf Logistiek was word op 1 Augustus 1978 aangestel as Hoof van Staf Logistiek. Alhoewel It-genl H.A. Kotzé eers op 31 Januarie 1979 met pensioen uit die diens van die SAW getree het, het hy op 1 Augustus 1978 diens as Projekleier van Spesiale Projekte aanvaar. Met die aftrede van It-genl H.A. Kotzé, is die pos van HSL(It-genl) gevries en die pos van A/HSL omskep na HSL(genl-maj). Genl-maj W.J. Coetser tree met ingang van 30 Junie 1978 met pensioen uit die diens van die SAW, maar bly aan in die Afdeling. Op 1 Desember 1979 word genl-maj I. Lemmer bevorder tot die substantiewe rang van It-genl met die gevolglike opgradering van HSL en die instelling van ' $n$ A/HSL-pos waarin Sadm A.C. Mandy op 1 Desember 1979 diens by Afdeling Logistiek aanvaar.

Die Direktoraat Kodifikasie en Katalogisering (DKK) is in 1979 herorganiseer deurdat die twee seksies plaaslike - en internasionale kodifikasie in een seksie kodifikasie en katalogisering saamgevoeg is. 'n Nuwe Seksie Stelselontwikkeling is gestig om die stelsel te ontwikkel en beter dienslewering aan die gebruikers van die Nasionale Katalogiseringstelsel daar te stel.

\section{Uitbreiding}

Ooreenkomstig die 1980 DOS-ondersoek, word Afdeling Logistiek van vyf na agt direktorate, wat Direktoraat Telekommunikasies (D Tels), met ingang van 1 Maart 1980 insluit, uitgebrei. Een bykomende generaalspos word ook geskep wat meebring dat daar onder HSL nou twee adjunkte is, nl Adjunk Hoof van Staf Logistiese Steun (A/HSL S) en Adjunk Hoof van Staf Logistiese Beplanning (A/HSL B). In hierdie twee adjunkposte word genl-maj D.M. Ralston en sadm A.C. Mandy onderskeidelik aangestel. 
Die volgende drie nuwe direktorate word gestig, $\mathrm{nl}$ die Direktoraat Logistiese Steun wat die Direktoraat Logistiese Operasies vervang; die Direktoraat Logistiese Ontwikkeling wat die Direktorate Programme, Materiaal en Fasiliteite vervang en die Direktoraat Logistiese Administrasie wat die onderafdeling Dienste vervang. Op $31 \mathrm{Mei}$ 1980 tree genl-maj D.M. Ralston met pensioen uit die diens van die SAW en die pos van A/HSL $S$ word tydelik deur genl-maj W.J. Coetser gevul. Op 1 Januarie 1981 sluit genl-maj J.F.J. van Rensburg, vorige Hoof van Leërstraf Logistiek by Afdeling Logistiek as A/HSL $S$ aan. Met ingang van 1 Mei 1981 word die adjunkposte met Hoofdirekteursposte vervang. Genl-maj J.F.J. van Rensburg word met ingang van 1 Januarie 1982 na die Staatsveiligheidsraad oorgeplaas en word deur genl-maj D.J. van Niekerk as Hoofdirekteur Logistiese Steun (HD Log S) vervang.
Genl-maj D.J. van Niekerk het voorheen die pos van Hoof van Lugstaf Logistiek by Lugmaghoofkwartier gevul.

\section{Slotopmerkings}

Afdeling Logistiek het in die bykans agt jaar van sy bestaan, gegroei tot ' $n$ sterk Stafafdeling met 215 lede, waaronder Staandemaglede, Nasionale Dienspligtiges en burgerlikes tel. Goeie samewerking tussen hierdie Afdeling, Weermagsdele, Ondersteuningsdienste, ander Stafafdelings en Krygkor word deurgaans gehandhaaf tot uitbouing van 'n doeltreffende logistiese masjien en voordeel van die SAW as geheel.

Maj A.C. Bergh BA Hons (Geskiedenis); LSOD, is verbonde aan die Afdeling Logistiek van die SAW. 